\title{
Synthesis and characterization of novel bioactive 1,2,4-oxadiazole natural product analogs bearing the $N$-phenylmaleimide and $N$-phenylsuccinimide moieties
}

\author{
Catalin V. Maftei ${ }^{1}$, Elena Fodor ${ }^{1}$, Peter G. Jones ${ }^{1}$, M. Heiko Franz ${ }^{2}$, \\ Gerhard Kelter ${ }^{3}$, Heiner Fiebig ${ }^{3}$ and Ion Neda ${ }^{*} 4, \S$
}

\section{Full Research Paper}

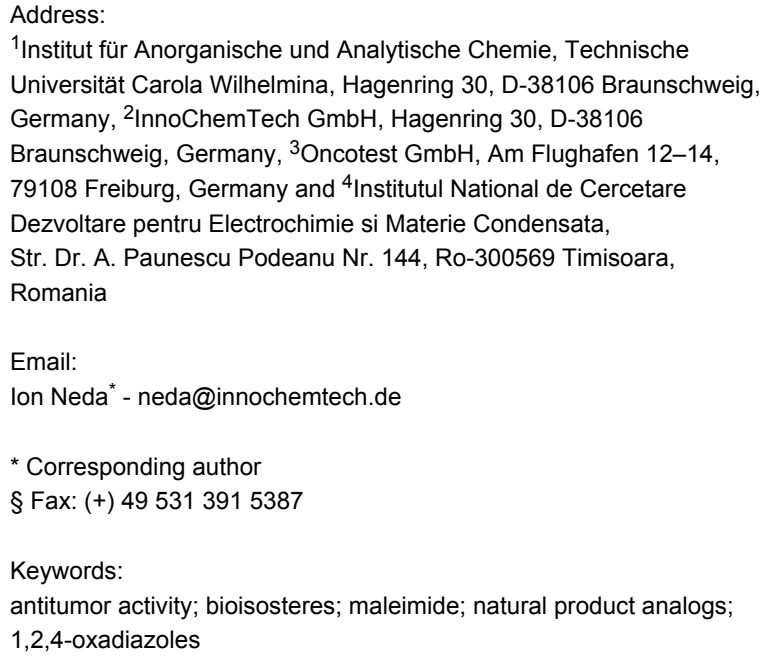

${ }^{1}$ Institut für Anorganische und Analytische Chemie, Technische Universität Carola Wilhelmina, Hagenring 30, D-38106 Braunschweig, Germany, ${ }^{2}$ InnoChemTech GmbH, Hagenring 30, D-38106 Braunschweig, Germany, ${ }^{3}$ Oncotest $\mathrm{GmbH}$, Am Flughafen 12-14, 79108 Freiburg, Germany and ${ }^{4}$ Institutul National de Cercetare Dezvoltare pentru Electrochimie si Materie Condensata, Str. Dr. A. Paunescu Podeanu Nr. 144, Ro-300569 Timisoara, Romania

Email:

Ion Neda* - neda@innochemtech.de

* Corresponding author

§ Fax: (+) 495313915387

Keywords:

antitumor activity; bioisosteres; maleimide; natural product analogs; 1,2,4-oxadiazoles

\author{
Beilstein J. Org. Chem. 2013, 9, 2202-2215. \\ doi:10.3762/bjoc. 9.259
}

Received: 01 August 2013

Accepted: 26 September 2013

Published: 25 October 2013

This article is part of the Thematic Series "Natural products in synthesis and biosynthesis".

Guest Editor: J. S. Dickschat

(C) 2013 Maftei et al; licensee Beilstein-Institut.

License and terms: see end of document.

\footnotetext{
Abstract

Taking into consideration the biological activity of the only natural products containing a 1,2,4-oxadiazole ring in their structure (quisqualic acid and phidianidines A and B), the natural product analogs 1-(4-(3-tert-butyl-1,2,4-oxadiazol-5-yl)phenyl)pyrrolidine2,5-dione (4) and 1-(4-(3-tert-butyl-1,2,4-oxadiazol-5-yl)phenyl)-1H-pyrrole-2,5-dione (7) were synthesized starting from 4-(3-tertbutyl-1,2,4-oxadiazol-5-yl)aniline (1) in two steps by isolating the intermediates 4-(4-(3-tert-butyl-1,2,4-oxadiazol-5-yl)phenylamino)-4-oxobutanoic acid (3) and (Z)-4-(4-(3-tert-butyl-1,2,4-oxadiazol-5-yl)phenylamino)-4-oxobut-2-enoic acid (6). The two natural product analogs 4 and 7 were then tested for antitumor activity toward a panel of 11 cell lines in vitro by using a monolayer cell-survival and proliferation assay. Compound 7 was the most potent and exhibited a mean $\mathrm{IC}_{50}$ value of approximately $9.4 \mu \mathrm{M}$. Aniline 1 was synthesized by two routes in one-pot reactions starting from tert-butylamidoxime and 4-aminobenzoic acid or 4-nitrobenzonitrile. The structures of compounds 1, 2, 4, 5 and 6 were confirmed by X-ray crystallography.
} 


\section{Introduction}

The five-membered heterocyclic 1,2,4-oxadiazole motif is of synthetic and pharmacological interest. It also forms an important constituent of biologically active compounds including natural products [1]. Sawyer et al. have described such compounds as bioisosteres for amides and esters [2], with the 1,2,4oxadiazoles showing higher hydrolytic and metabolic stability.

To the best of our knowledge, there are only a few examples of natural products with a 1,2,4-oxadiazole core or a structure based on it. The 3-substituted indole alkaloids, phidianidines A and B (Figure 1), have been isolated by Carbone et al. from the aeolid opisthobranch Phidiana militaris [3]. They are selective inhibitors of the dopamine transporter DAT and partial agonists of the $\mu$ opioid receptor [4]. Moreover, these selective molecules are attractive as CNS targets because neither phidianidine A nor B is cytotoxic. Another example of a natural product with a oxadiazole core is quisqualic acid (Figure 1). This metabolite was obtained from the seeds of Quisqualis indica and Q. fructus $[5,6]$ and is a strong agonist for AMPA ( $\alpha$-amino-3-hydroxy-5methyl-4-isoxazolepropionic acid) receptors and group I metabotropic glutamate receptors [7].

Furthermore, 1,2,4-oxadiazoles are widely used in synthetic chemistry, e.g., in the search for antitumor agents. Cancer consists of more than one hundred different diseases, all of which are characterized by the uncontrolled growth and spread of abnormal cells. In this context, the identification of drugs acting as apoptosis inducers represents an attractive approach for the discovery of new anticancer agents. 1,2,4-oxadiazole $\mathbf{A}$ (Figure 2) was found to act as an apoptosis agent by a highthroughput screening (HTS) assay [8]. A series of 1,2,4-oxadiazole-5-carboxamides $\mathbf{B}$ have been synthesized and tested as inhibitors of the glycogen synthase kinase 3 (GSK-3), a key regulator of both differentiation and cellular proliferation [9].

An alternative antitumor strategy involves the inhibition of processes involved in tumor growth, e.g., angiogenesis. Integrin $\alpha_{\mathrm{v}} \beta_{3}$ is a receptor that has been found on the surface of many tumor cells and recognizes the arginine-glycine-aspartic

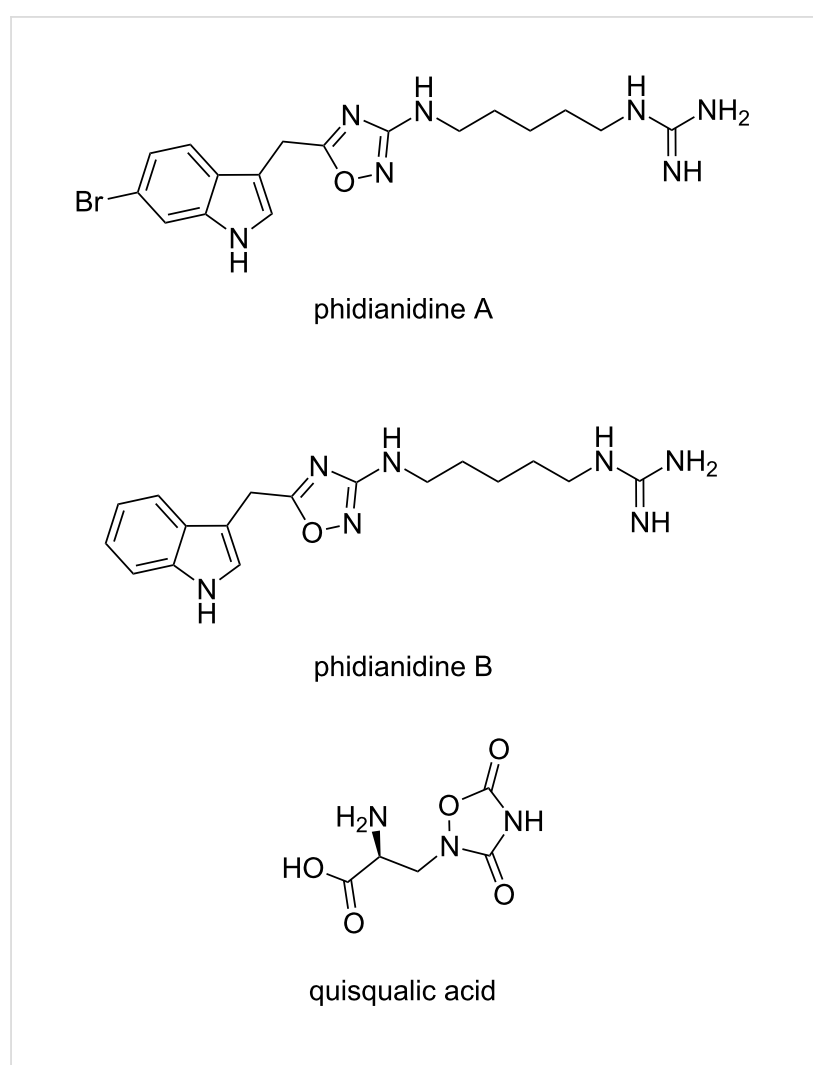

Figure 1: Natural products having a 1,2,4-oxadiazole core.

acid (RGD) sequence. Antagonists of this receptor are able to inhibit angiogenesis. 1,2,4-Oxadiazolebutanoic acids such as $\mathbf{C}$ were tested as non-peptidic analogs of $\alpha_{v} \beta_{3}$ antagonists [10]. Furthermore, substituted 1,2,4-oxadiazoles have been described as antirhinovirals [11], benzodiazepine receptor partial agonists [12], anti-inflammatory [13], muscarinic agonists [14], serotoninergic (5-HT 3 ) antagonists [15], and growth hormone secretagogues [16].

The maleimide motif is also a useful five-membered heterocycle in pharmacological chemistry. Kratz et al. synthesized maleimide derivatives of doxorubicin and camptothecin. After intravenous administration these designed anticancer drugs bind<smiles>FC(F)(F)c1ccc(-c2noc(-c3sccc3Cl)n2)cc1</smiles>

A<smiles>[R]CN1CC([R])N(CCCNC(=O)c2nc([Al])no2)CC1[R]</smiles>

B<smiles>O=C(O)CC(Cc1nc(CCCCNc2cc(N3CCSCC3)ccn2)no1)c1ccc2c(c1)OCO2</smiles>

C

Figure 2: Examples of 1,2,4-oxadiazole antitumorals. 
rapidly to circulating albumin [17-19]. Endogenous albumin could be seen as a drug carrier, as it accumulates in solid tumors according to the pathophysiology of tumor tissue [20,21]. Therefore, designed prodrugs have a higher antitumor efficacy in vivo than drugs. Furthermore, maleimides possess strong antifungal activities against important human opportunistic pathogenic fungi. These antifungal drugs appear to be excellent candidates for further development [22-27]. Barrett et al. point out that the possibility of performing chemical modifications is a requirement for developing novel drugs, a strong activity is just the starting point [28].

Another moiety worth investigation is succinimide, because $\mathrm{N}$-phenylsuccinimides are regarded as some of the most efficacious agricultural fungicides $[29,30]$. They have also been shown to be selective nephrotoxic compounds [31,32].

Considering natural products with the 1,2,4-oxadiazol moiety, such as phidianidines A and B (selective inhibitors of DAT), we decided to synthesize, isolate and characterize novel natural product analogs of 1,2,4-oxadiazole derivatives bearing $\mathrm{N}$-phenylmaleimide or $\mathrm{N}$-phenylsuccinimide functionalities in order to improve their biological activity. The new derivatives have been tested for in vitro antitumor activity toward a panel of 11 cell lines.

\section{Results and Discussion}

Clapp reviewed the synthesis of 1,2,4-oxadiazoles [33]. He pointed out that two general methods dominate the practical preparation $(\approx 95 \%)$ : (a) The condensation of amidoximes with carboxylic acid derivatives.

(b) The dipolar cycloaddition of nitrile oxides to nitriles.

The general approach for the synthesis of 1,2,4-oxadiazoles is illustrated in Scheme 1.

Using route (a), the amidoxime route, the carboxylic acid has to be employed in an activated form. The activated carboxylic acid can be prepared beforehand or in situ by several methods [34], e.g., as an acyl chloride or by the use of $N, N^{\prime}$-carbonyldiimidazole (CDI). In the first step the amidoxime is $O$-acylated with the activated derivative in a condensation reaction. The $O$-acylated amidoxime can be isolated or it can immediately undergo the cyclisation to the heterocyclic oxadiazole ring. This cyclodehydration reaction takes place by heating to temperatures above $100{ }^{\circ} \mathrm{C}[35,36]$. Microwave techniques have also been employed in the synthesis of such heterocycles. The advantage of CDI is that it activates the carboxylic acid in situ and can be used for step 1 and step 2 in DMF.

Scheme 2 presents the one-pot synthesis of 4-(3-tert-butyl1,2,4-oxadiazol-5-yl)aniline (1) starting from tert-butylamidoxime and 4-aminobenzoic acid. Activation of the 4-aminobenzoic acid with CDI and further acylation of the tert-butylamidoxime with DMF as a solvent furnished the $O$-acylamidoxime, which was not isolated. After heating to $120^{\circ} \mathrm{C}$ for four hours, it underwent a cyclodehydration reaction, delivering aniline $\mathbf{1}$ with $59 \%$ yield after purification.

$$
\text { (b) }
$$




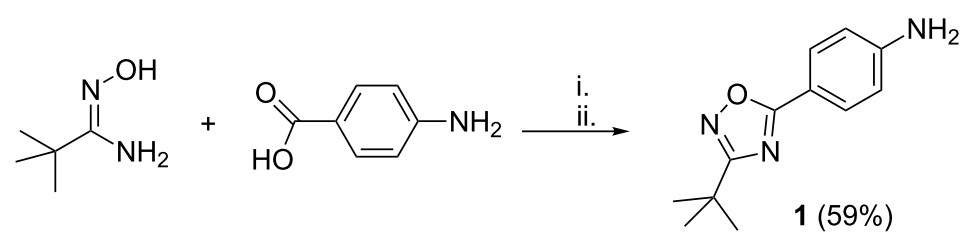

Scheme 2: One-pot synthesis of 4-(3-tert-butyl-1,2,4-oxadiazol-5-yl)aniline (1) by using the amidoxime route. i. 1.1 equiv CDI in DMF, 30 minutes; ii. 1.1 equiv $\mathrm{CDI}$ in DMF, $120^{\circ} \mathrm{C}, 4 \mathrm{~h}$.

The structure of compound 1 was confirmed by X-ray structure determination (Figure 3 and Figure 4). It crystallizes with two molecules in the asymmetric unit, which differ in the relative orientation of the rings (interplanar angles $22^{\circ}$ and $9^{\circ}$ ). Three of the four NH hydrogens are involved in hydrogen bonds, leading to ribbons of $\mathrm{H}$-bonded rings parallel to the $a$ axis.
Following the second route, the 1,3-dipolar cycloaddition, with the purpose of increasing the yield of compound 1, we used $p$-toluenesulfonic acid (PTSA)- $\mathrm{ZnCl}_{2}$ as a catalyst for the synthesis of aniline $\mathbf{1}$ from amidoximes and organic nitriles [37]. tert-Butylamidoxime and 4-aminobenzonitrile were mixed in DMF with catalytic amounts of PTSA- $\mathrm{ZnCl}_{2}$. First, tert-butyl-
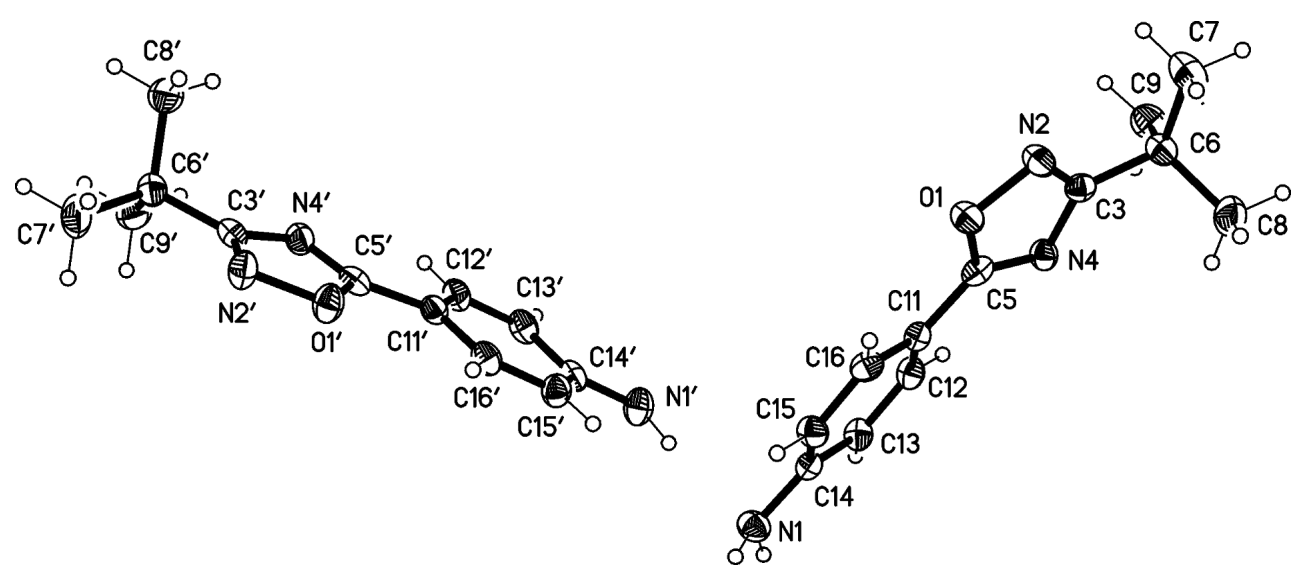

Figure 3: Molecular structure of 4-(3-tert-butyl-1,2,4-oxadiazol-5-yl)aniline (1). Atoms are drawn as $50 \%$ thermal ellipsoids. One hydrogen at N1' is eclipsed.

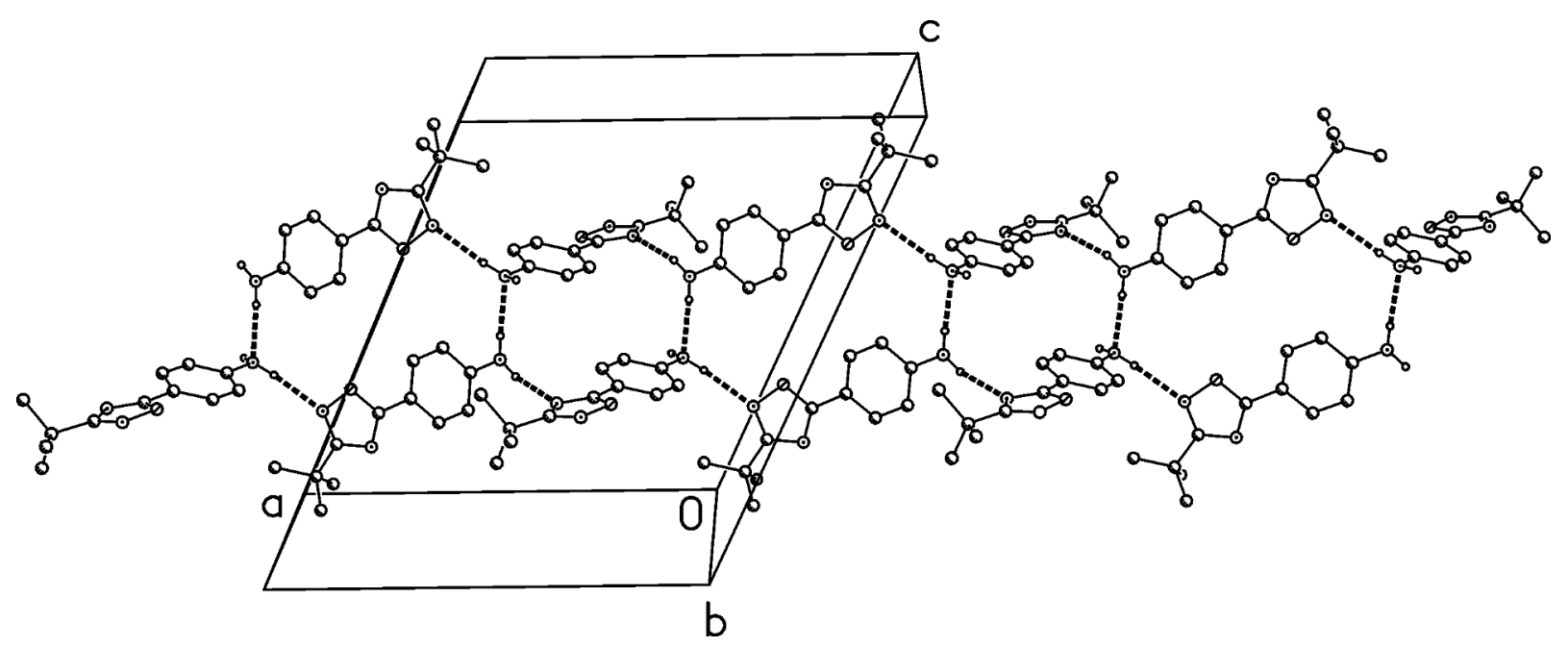

Figure 4: Packing diagram of compound 1. Hydrogen bonds are indicated as dashed lines. 
amidoxime is activated by PTSA- $\mathrm{ZnCl}_{2}$; resulting in the formation of a Lewis acid-ammonia complex as a leaving group, giving rise to the formation of the nitrile oxide. The 1,2,4oxadiazole moiety is established by the 1,3-dipolar cycloaddition of nitrile oxide to the 4-aminobenzonitrile. However, the Lewis acid might also be involved in the formation of the heterocycle via a Lewis acid catalyzed [3 +2$]$ cycloaddition reaction. Unfortunately, the yield for this reaction was very low $(<20 \%)$.

In order to obtain compound $\mathbf{1}$ by the 1,3 dipolar cycloaddition route we changed the protocol. We synthesized the nitro derivative 2 (3-tert-butyl-5-(4-nitrophenyl)-1,2,4-oxadiazole) in situ by using the same catalyst pair as in the first synthesis route. Then, we attempted to hydrogenate nitro compound $\mathbf{2}$ to the corresponding amine $\mathbf{1}$ in the same reaction pot without having to isolate the intermediate. The overall yield in this case was $64 \%$. The intermediate 2 was isolated to be fully charazterized. After a series of tests by using various acids as catalyst ( $p$-toluensulfonic acid (PTSA), 2-mesitylenesulfonic acid (MSA) and methanesulfonic acid (MeSA) in combination with $\mathrm{ZnCl}_{2}$ and $\mathrm{ZnBr}_{2}$ ), MSA- $\mathrm{ZnBr}_{2}$ in acetonitrile proved to be the best combination for the preparation of compound $\mathbf{2}$ from tert-butylamidoxime and 4-nitrobenzonitrile under mild conditions. The results are summarized in Table 1 . The optimized yield was 93\% (Scheme 3) which makes this route more practical than the amidoxime route presented in Scheme 2 with a yield of only $59 \%$.

The structure of compound $\mathbf{2}$ was confirmed by X-ray structure determination (Figure 5 and Figure 6). The interplanar angle in compound 2 is only $3^{\circ}$ and the molecules are

\begin{tabular}{|c|c|c|c|c|c|}
\hline Entry & Catalyst 1 & Catalyst 2 & Solvent & Time (h) & Yield (\%) \\
\hline 1 & PTSA & $\mathrm{ZnCl}_{2}$ & DMF & 5 & 64 \\
\hline 2 & MSA & $\mathrm{ZnCl}_{2}$ & DMF & 3 & 76 \\
\hline 3 & MeSA & $\mathrm{ZnCl}_{2}$ & DMF & 12 & 56 \\
\hline 4 & PTSA & $\mathrm{ZnBr}_{2}$ & DMF & 5 & 70 \\
\hline 5 & MSA & $\mathrm{ZnBr}_{2}$ & DMF & 3 & 79 \\
\hline 6 & MeSA & $\mathrm{ZnBr}_{2}$ & DMF & 12 & 58 \\
\hline 7 & PTSA & $\mathrm{ZnCl}_{2}$ & $\mathrm{MeCN}$ & 2 & 82 \\
\hline 8 & MSA & $\mathrm{ZnCl}_{2}$ & $\mathrm{MeCN}$ & 2 & 92 \\
\hline 9 & MeSA & $\mathrm{ZnCl}_{2}$ & $\mathrm{MeCN}$ & 12 & 63 \\
\hline 10 & PTSA & $\mathrm{ZnBr}_{2}$ & $\mathrm{MeCN}$ & 2 & 86 \\
\hline 11 & MSA & $\mathrm{ZnBr}_{2}$ & $\mathrm{MeCN}$ & 2 & 93 \\
\hline 12 & MeSA & $\mathrm{ZnBr}_{2}$ & $\mathrm{MeCN}$ & 12 & 65 \\
\hline
\end{tabular}

${ }^{a}$ General conditions: tert-butylamidoxime (1 equiv), 4-nitrobenzonitrile (1 equiv), catalyst 1 ( 0.3 equiv), catalyst $2\left(0.3\right.$ equiv), $80{ }^{\circ} \mathrm{C}$.

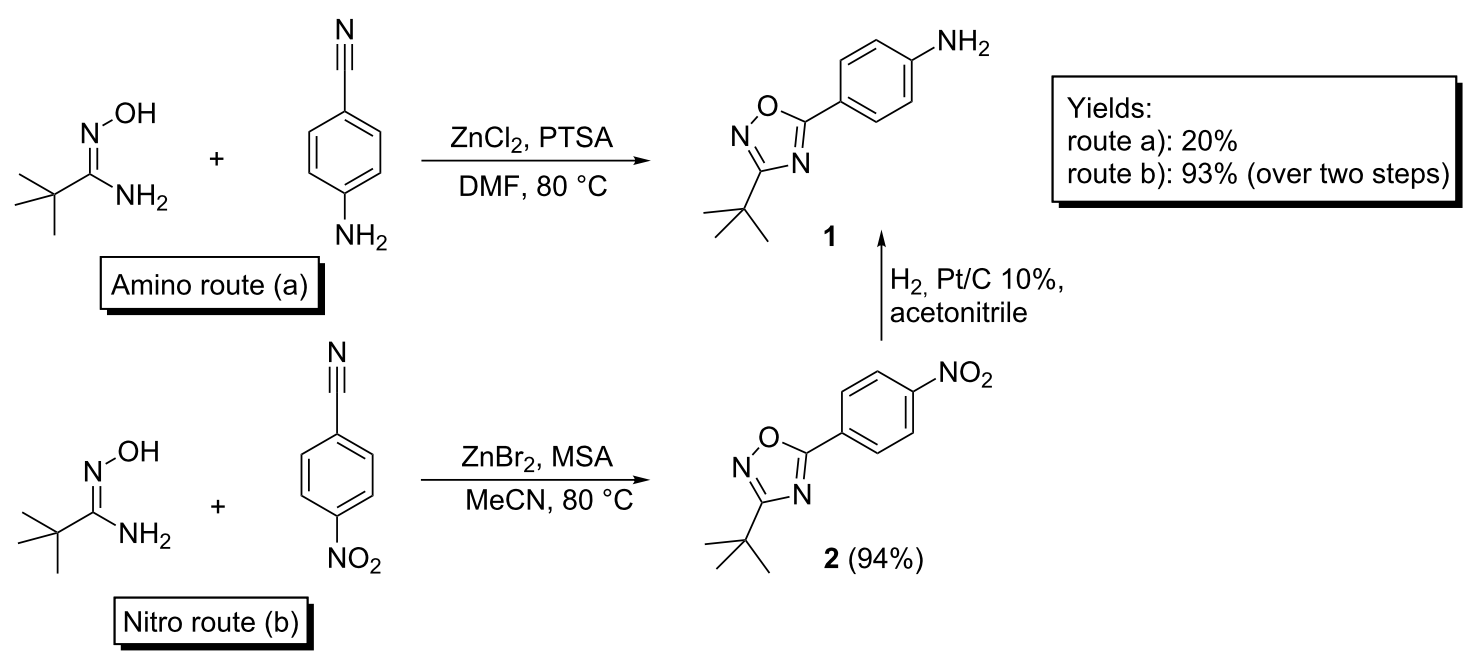


linked to ribbons parallel to the $b$ axis by two $\mathrm{C}-\mathrm{H} \cdots \mathrm{O}$ interactions.

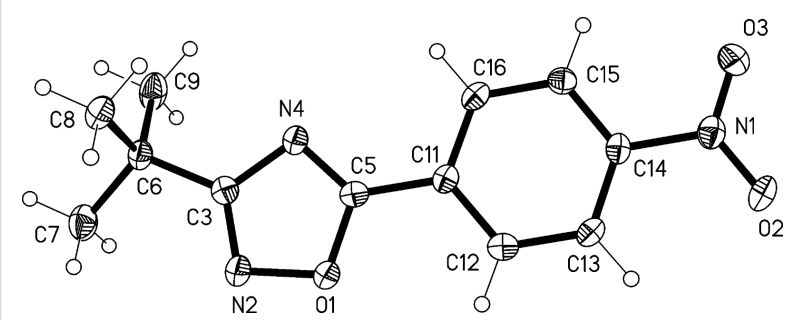

Figure 5: Molecular structure of 3-tert-butyl-5-(4-nitrophenyl)-1,2,4oxadiazole (2). Atoms are drawn as $50 \%$ thermal ellipsoids.

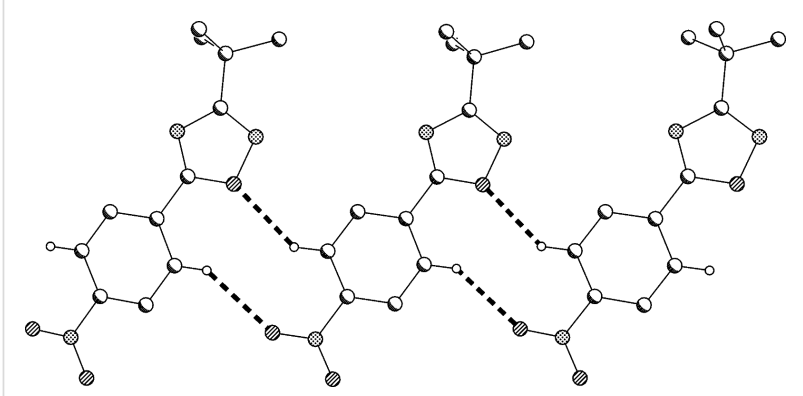

Figure 6: Packing diagram of compound (2) showing $\mathrm{C}-\mathrm{H} \cdots \mathrm{O}$ interactions.

Imide derivatives have been found to possess a broad spectrum of biological activities. A variety of methods have been reported for the preparation of this class of compounds. The synthesis follows a two-step protocol. First, it is necessary to synthesize the amide derivative.
The synthesis of amide $\mathbf{3}$ was performed under inert conditions by mixing an equimolar amount of aniline $\mathbf{1}$ and succinic anhydride in a minimum volume of dichloromethane (Scheme 4). Compound 3 was obtained with a short reaction time and a high yield (91\%). The ester derivative methyl 4-(4-(3-tert-butyl1,2,4-oxadiazol-5-yl)phenylamino)-4-oxobutanoate (5) was prepared by the addition of a diethyl ether solution of diazomethane to a suspension of amide 3. The ester 5 was afforded in a quantitative amount.

For the synthesis of imide $\mathbf{4}$ the starting material, amide $\mathbf{3}$, was mixed with an equimolar amount of sodium acetate in acetic anhydride and the mixture was heated for $4 \mathrm{~h}$ at $80-85{ }^{\circ} \mathrm{C}$; resulting in the corresponding $N$-arylsuccinimide 4 (87\%).

The structures of compounds $\mathbf{4}$ and $\mathbf{5}$ were also confirmed by X-ray structure analysis (Figure 7, Figure 8 and Figure 9). In compound $\mathbf{4}$ the oxazoline and phenyl rings are approximately coplanar $\left(6^{\circ}\right)$, but the pyrrolidine ring is rotated by $52^{\circ}$ with respect to the phenyl ring. The main packing interaction is an

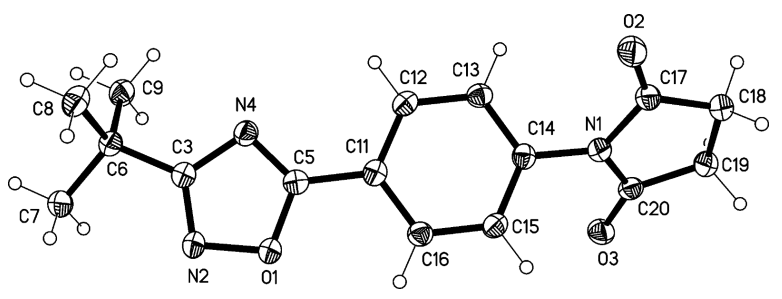

Figure 7: Molecular structure of 1-(4-(3-tert-butyl-1,2,4-oxadiazol-5yl)phenyl)pyrrolidine-2,5-dione (4). Atoms are drawn as $50 \%$ thermal ellipsoids.<smiles>CC(C)(C)c1noc(-c2ccc(N)cc2)n1</smiles><smiles>COC(=O)CCC(=O)Nc1ccc(-c2nc(C(C)(C)C)no2)cc1</smiles> 


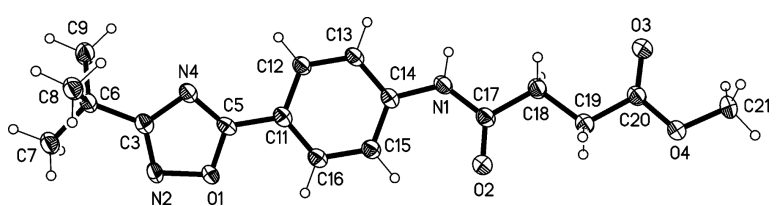

Figure 8: Molecular structure of 4-(4-(3-tert-butyl-1,2,4-oxadiazol-5yl)phenylamino)- 4 oxobutanoate (5). Atoms are drawn as $50 \%$ thermal ellipsoids.

offset stacking parallel to the $c$ axis (not shown). Compound $\mathbf{5}$ has an interplanar angle of $14^{\circ}$. The molecules are associated into ribbons parallel to [110] by one long $\mathrm{N}-\mathrm{H} \cdots \mathrm{N}$ and two shorter $\mathrm{C}-\mathrm{H} \cdots \mathrm{O}$ interactions.

The synthesis of amide 6 was performed by mixing an equimolar amount of aniline $\mathbf{1}$ and maleic anhydride in dichloromethane (Scheme 5). The amide $\mathbf{6}$ was obtained with a good yield (84\%). For the synthesis of imide 7 the amide 6 was mixed with an equimolar amount of sodium acetate in acetic anhydride and the mixture was heated for $4 \mathrm{~h}$ at $80-85^{\circ} \mathrm{C}$ resulting in the corresponding $N$-arylmaleimide 7 (75\%).

The structure of compound $\mathbf{6}$ was also confirmed by X-ray structure analysis (Figure 10 and Figure 11). In compound 6 the

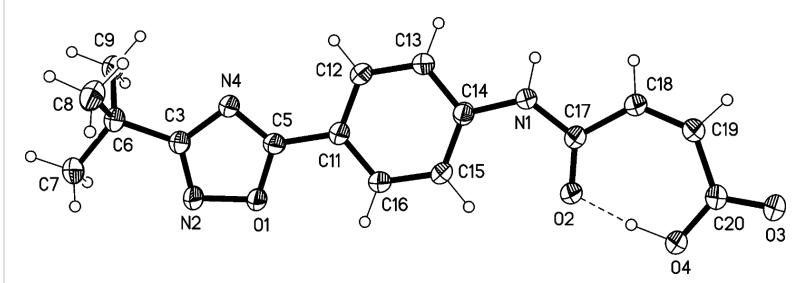

Figure 10: Molecular structure of (Z)-4-(4-(3-tert-butyl-1,2,4-oxadiazol5 -yl)phenylamino)-4-oxobut-2-enoic acid (6). Atoms are drawn as $50 \%$ thermal ellipsoids.

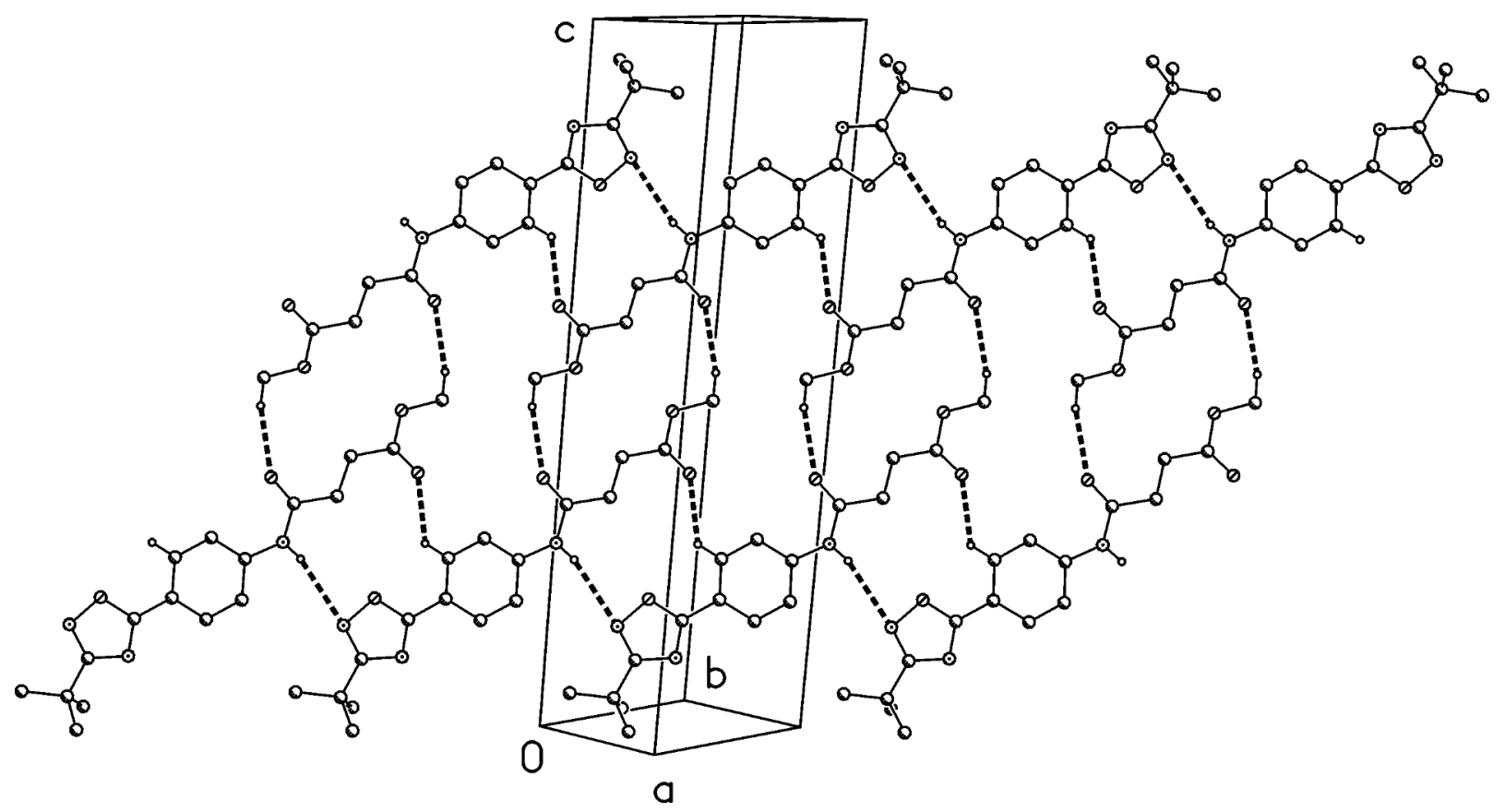

Figure 9: Packing diagram of compound (5). Dashed lines indicate hydrogen bonds.<smiles></smiles> 


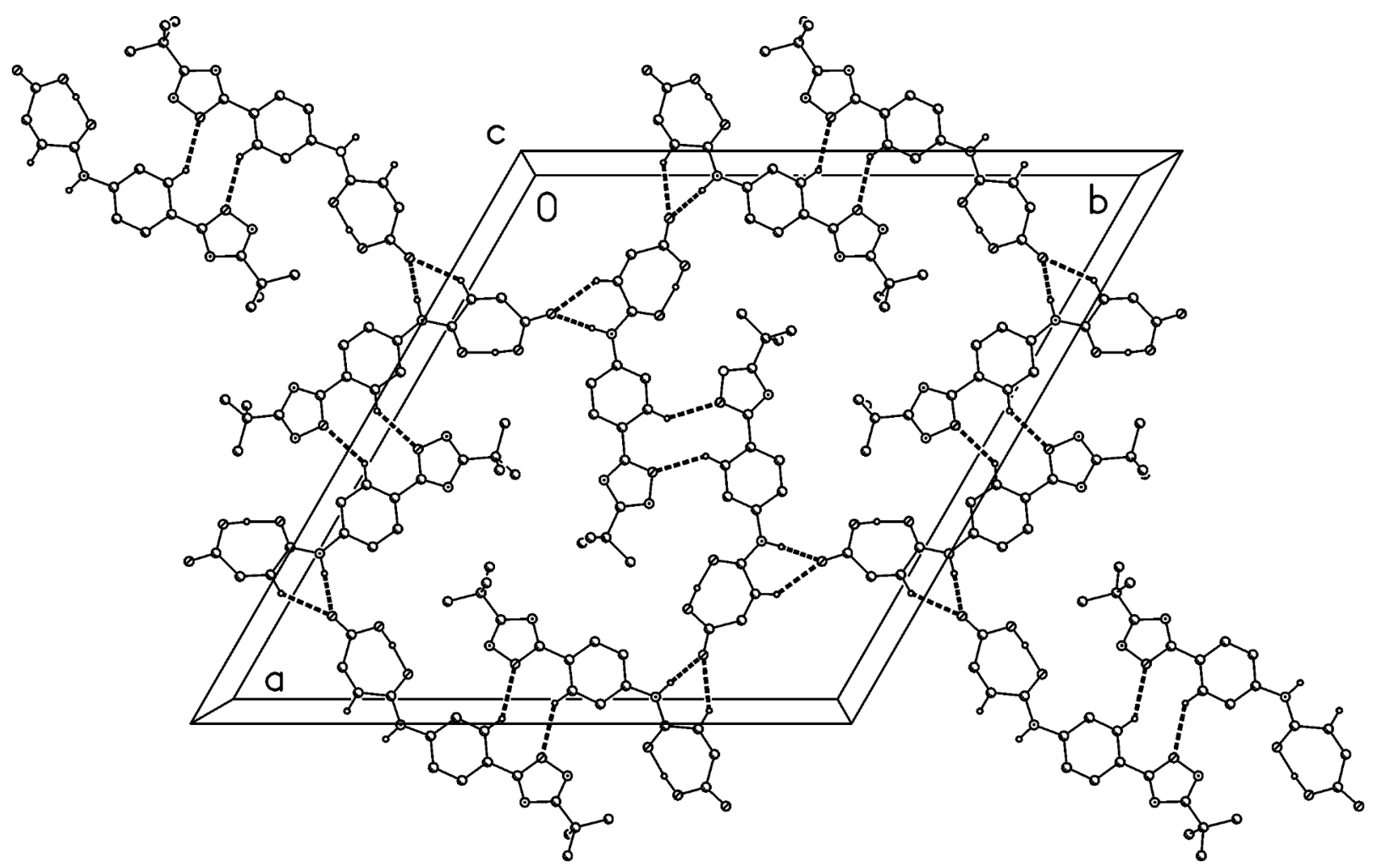

Figure 11: Packing diagram of compound 6. Dashed lines indicate hydrogen bonds.

interplanar angle is $11^{\circ}$; the intramolecular hydrogen bond is

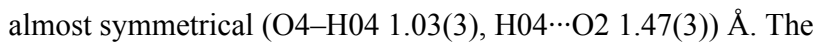
molecules are linked to form layers perpendicular to the hexagonal $c$ axis by one $\mathrm{C}-\mathrm{H} \cdots \mathrm{O}$ and one three-centre $(\mathrm{N}-\mathrm{H}$, $\mathrm{C}-\mathrm{H}) \cdots \mathrm{O}$ interaction. The double bond has a $\mathrm{Z}$-configuration.

\section{Antitumor activity}

The in vitro antitumor activity of six synthesized compounds toward a panel of 11 cell lines was assessed by using a monolayer cell survival and proliferation assay. By exhibiting a mean $\mathrm{IC}_{50}$ value of $9.4 \mu \mathrm{M} 7$ was the most potent compound. Compounds 1, 5, 4, 6 and 3 have only marginal antitumor activity toward the 11 tested cell lines (Figure 12).

An investigation of the activity of compounds in a cell line panel representing various tumor histo-types, as performed in this study, allows the analysis of potency and tumor selectivity and the identification of active compounds which qualify for further preclinical development. Tumor selectivity of the compounds is illustrated in Figure 13 by a heat-map presentation of the individual $\mathrm{IC}_{50}$ values. Good tumor selectivity is reflected by cell lines exhibiting above-average sensitivity (i.e., an individual $\mathrm{IC}_{50}$ value smaller than 0.5 of the mean $\mathrm{IC}_{50}$ value;

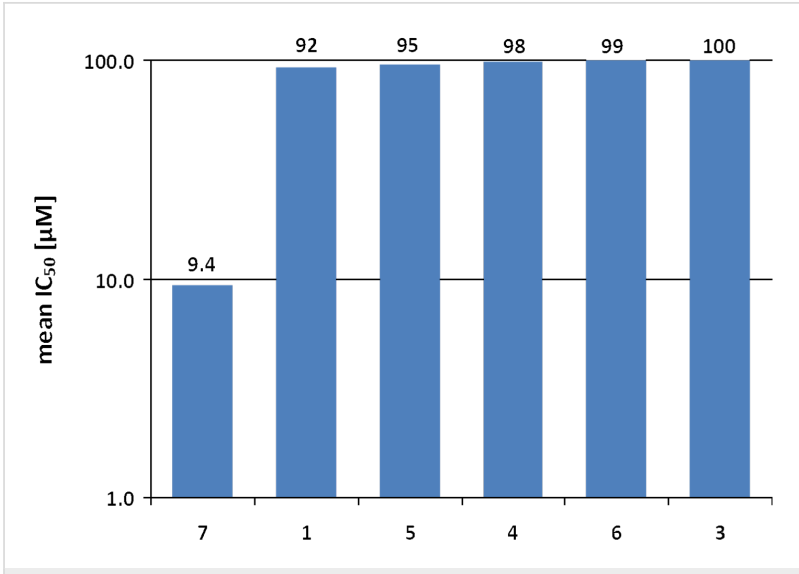

Figure 12: In vitro antitumor activity of compounds 1, 3-7 toward 11 human tumor cell lines.

marked in green) and the range of activity among the cell lines (i.e., the $\mathrm{IC}_{50}$ value of the most resistant cell line divided by the $\mathrm{IC}_{50}$ value of the most sensitive cell line). Overall, a good antitumor potency (i.e., a mean $\mathrm{IC}_{50}<30 \mu \mathrm{M}$ ) combined with a good selectivity (i.e., a range of activity $>8$ or at least 2 cell lines exhibiting above-average sensitivity) was obvious for compound 7 . 


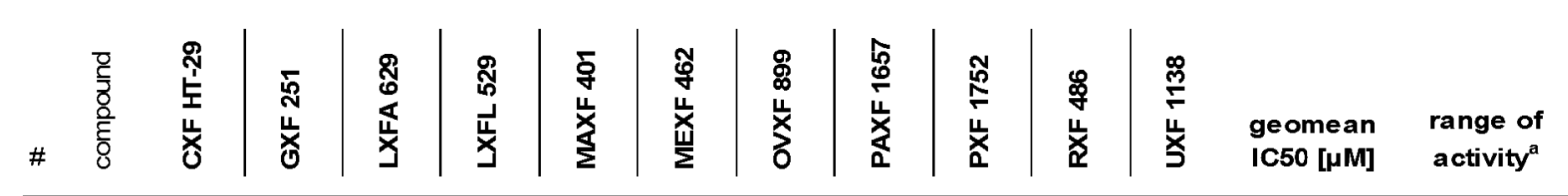

\begin{tabular}{|c|c|c|c|c|c|c|c|c|c|c|c|c|c|}
\hline 7 & 15.00 & 28.12 & 22.01 & 6.92 & 9.26 & 7.76 & 10.93 & 3.94 & 11.10 & 4.49 & 5.05 & 9.39 & 7.1 \\
\hline 1 & 100.00 & 55.33 & 100.00 & 76.78 & 98.08 & 100.00 & 100.00 & 100.00 & 100.00 & 100.00 & 100.00 & 92.4 & 1.8 \\
\hline 5 & 100.00 & 100.00 & 100.00 & 57.28 & 100.00 & 100.00 & 100.00 & 100.00 & 100.00 & 100.00 & 100.00 & 95.1 & 1.7 \\
\hline 4 & 100.00 & 100.00 & 100.00 & 82.92 & 100.00 & 100.00 & 100.00 & 100.00 & 100.00 & 100.00 & 100.00 & 98.3 & 1.2 \\
\hline 6 & 100.00 & 92.39 & 100.00 & 100.00 & 100.00 & 100.00 & 100.00 & 100.00 & 100.00 & 100.00 & 100.00 & 99.3 & 1.1 \\
\hline 3 & 100.00 & 100.00 & 100.00 & 100.00 & 100.00 & 100.00 & 100.00 & 100.00 & 100.00 & 100.00 & 100.00 & 100.0 & 1.0 \\
\hline
\end{tabular}

${ }^{\mathrm{a}}$ IC50 value of the most resistant cell line divided by the IC50 value of the most senstive cell line

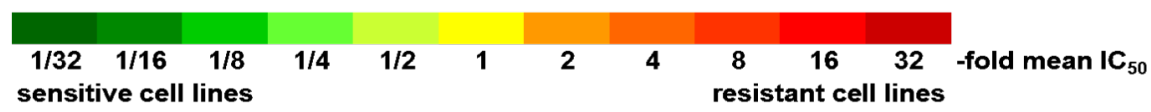

Figure 13: Individual $\mathrm{IC}_{50}$ values $[\mu \mathrm{M}]$ of compounds 1, 3-7 in a panel of 11 human tumor cell lines.

\section{Conclusion}

Two novel 1,2,4-oxadiazol natural product-inspired derivatives bearing $N$-phenylmaleimide or $N$-phenylsuccinimide moieties were synthesized in two steps starting from 1,2,4-oxadiazole amine 1. All intermediate derivatives were isolated, characterized and tested in vitro for antitumor activity toward a panel of 11 cell lines by using a monolayer cell survival and proliferation assay. With an $\mathrm{IC}_{50}$ value of $9.4 \mu \mathrm{M}$, compound 7 was the most active, probably because maleimide is able to rapidly bind to the cysteine-34 position of circulating albumin, transported as an albumin conjugate (macromolecular drug), and then released in the target tissue by acid related cleavage or enzymatic cleavage. Compounds 1, 3, 4, 5 and 6 have no or only marginal activity toward the 11 cell lines tested. Considering the bioactive natural products (quisqualic acid and phidianidines A and B), it is of great pharmacologic interest to synthesize new derivates of 1,2,4-oxadiazole with an efficient biological transport in cells by using natural transporters such as amino acids, peptides or sugars. Moreover, it is desirable to reduce, or even remove completely, the secondary effects to minimize the toxicity and increase the selectivity. All derivatives were obtained with a high purity (at least $97 \%$ based on ${ }^{1} \mathrm{H}$ NMR) and good to high yields (75-96\%). The structural assignments were corroborated by X-ray structure analysis.

\section{Experimental \\ General}

All reagents were purchased from commercial sources (SigmaAldrich or Acros) and used without further purification. Solvents were of analytical grade. ${ }^{1} \mathrm{H}$ and ${ }^{13} \mathrm{C}$ NMR spectra were recorded at room temperature on a Bruker Avance 200 operating at $200 \mathrm{MHz}$ for ${ }^{1} \mathrm{H}$ and $50 \mathrm{MHz}$ for ${ }^{13} \mathrm{C}$. Chemical shifts $(\delta)$ are reported relative to the tetramethylsilane peak set at $0.00 \mathrm{ppm}$. In the case of multiplets, the signals are reported as intervals. Signals were abbreviated as s, singlet; $d$, doublet; $t$, triplet; q, quadruplet; m, multiplet. IR spectra were recorded with a Bruker Vertex 70 ATR. Mass spectra (electronic ionisation, $70 \mathrm{eV}$ ) were recorded on a Finnigan MAT 8400-MSS and Finnigan MAT 4515. High resolution mass spectra were recorded on a Finnigan MAT 95 XP. Melting points were measured with a Schropp Gerätetechnik MPM-HV2. The melting points are uncorrected. Column chromatography was carried out by using Merck silica gel 60 (70-200 mesh).

\section{Procedures}

Synthesis of 4-(3-tert-butyl-1,2,4-oxadiazol-5-

yl)aniline (1)

a. $1.0 \mathrm{~g}$ (7.2 mmol) of 4-aminobenzoic acid was dissolved under an inert atmosphere in $20 \mathrm{~mL}$ of DMF, and $1.28 \mathrm{~g}(7.9 \mathrm{mmol})$ of CDI solved in $30 \mathrm{~mL}$ of DMF was added. After 30 minutes of stirring at room temperature $0.91 \mathrm{~g}(7.9 \mathrm{mmol})$ of tert-butylamidoxime was added. A second portion of CDI (1.28 g, $7.9 \mathrm{mmol}$ ) was added, and the reaction mixture was heated under reflux until the reaction was complete. The mixture was cooled to room temperature and poured into $500 \mathrm{~mL}$ of water-ice mixture. The formed solid was filtered off, washed with water, dried and flash chromatographed (silica, ethyl acetate/hexane $2: 1$ ), yielding after purification $0.92 \mathrm{~g}$ (4.2 mmol, 59\%) of $\mathbf{1}$ as a yellow solid.

b. To a mixture of $0.116 \mathrm{~g}(1 \mathrm{mmol})$ of tert-butylamidoxime in $5 \mathrm{~mL}$ of solvent (acetonitrile or DMF) under an inert atmosphere was added $0.15 \mathrm{~g}(1 \mathrm{mmol})$ of 4-nitrobenzonitrile. To this reaction mixture was added $0.3 \mathrm{mmol}$ of acid catalyst 1 (57.0 mg PTSA, $70.8 \mathrm{mg}$ MSA or $28.8 \mathrm{mg} \mathrm{MeSA}$ ) and $0.3 \mathrm{mmol}$ of catalyst 2 (40.9 $\mathrm{mg} \mathrm{ZnCl}_{2}$ or $67.5 \mathrm{mg} \mathrm{ZnBr}$ ), and 
the mixture was heated to $80{ }^{\circ} \mathrm{C}$ until no further change was observed (2-12 hours). Then the reaction mixture was cooled to room temperature, $10 \mathrm{mg}$ of $\mathrm{Pt} / \mathrm{C} 10 \%$ catalyst was added, and hydrogen was bubbled through the solution until intermediate 2 was no longer detected. The reaction mixture was filtered through a layer of Celite, and then the solvent was removed under reduced pressure. The solid that remained was dried and flash chromatographed (silica, ethyl acetate/hexane 2:1), yielding after purification 1 as a yellow solid. Yield: PTSA/ $\mathrm{ZnCl}_{2} / \mathrm{DMF} 139.0 \mathrm{mg}, 0.64 \mathrm{mmol}, 64 \%$; MSA/ZnCl $2 / \mathrm{DMF}$ $165.0 \mathrm{mg}, 0.76 \mathrm{mmol}, 76 \%$; $\mathrm{MeSA} / \mathrm{ZnCl}_{2} / \mathrm{DMF} 121.6 \mathrm{mg}$, $0.56 \mathrm{mmol}, 56 \%$; PTSA/ZnBr $2 / \mathrm{DMF} 152.0 \mathrm{mg}, 0.7 \mathrm{mmol}$, $70 \%$; MSA/ZnBr 2 DMF $171.5 \mathrm{mg}, 0.79 \mathrm{mmol}, 79 \%$; MeSA/ $\mathrm{ZnBr}_{2} / \mathrm{DMF} 125.9 \mathrm{mg}, 0.58 \mathrm{mmol}, 58 \%$; PTSA$/ \mathrm{ZnCl}_{2} / \mathrm{CH}_{3} \mathrm{CN}$ $178.1 \mathrm{mg}, 0.82 \mathrm{mmol}, 82 \%$; $\mathrm{MSA} / \mathrm{ZnCl}_{2} / \mathrm{CH}_{3} \mathrm{CN} 199.8 \mathrm{mg}$, $0.92 \mathrm{mmol}, 92 \%$; $\mathrm{MeSA} / \mathrm{ZnCl}_{2} / \mathrm{CH}_{3} \mathrm{CN} 136.8 \mathrm{mg}, 0.63 \mathrm{mmol}$, 63\%; PTSA/ZnBr $2 / \mathrm{CH}_{3} \mathrm{CN} 186.7 \mathrm{mg}, 0.86 \mathrm{mmol}, 86 \%$; MSA/ $\mathrm{ZnBr}_{2} / \mathrm{CH}_{3} \mathrm{CN} 201.9 \mathrm{mg}, 0.93 \mathrm{mmol}, 93 \%$; $\mathrm{MeSA} / \mathrm{ZnBr}_{2} /$ $\mathrm{CH}_{3} \mathrm{CN} 141.1 \mathrm{mg}, 0.65 \mathrm{mmol}, 65 \%$. MS m/z: $217\left(\mathrm{M}^{+}, 60\right), 202$ (5), 120 (100); HRMS: calcd. for $\mathrm{C}_{12} \mathrm{H}_{15} \mathrm{~N}_{3} \mathrm{O}^{+}, 217.12096$; found, 217.12159; ${ }^{1} \mathrm{H} \mathrm{NMR}\left(200 \mathrm{MHz}, \mathrm{CDCl}_{3}\right) \delta 7.87-7.78$ $(\mathrm{m}, 2 \mathrm{H}), 6.68-6.56(\mathrm{~m}, 2 \mathrm{H}), 4.08(\mathrm{bs}, 2 \mathrm{H}), 1.32(\mathrm{~s}, 9 \mathrm{H}) ;{ }^{13} \mathrm{C}$ NMR $\left(50 \mathrm{MHz}, \mathrm{CDCl}_{3}\right) \delta 27.8\left(-\mathrm{CH}_{3}\right), 31.7,113.5,113.7$, 129.1, 149.7, 174.7, 177.3; mp 120-122 ${ }^{\circ} \mathrm{C}$; IR (ATR): 1/ $\lambda$ 3437 (w), 3326 (w), 3218 (w), 2966 (w), 2360 (w), 2162 (w), $1699(\mathrm{w}), 1652(\mathrm{w}), 1603$ (s), $1581(\mathrm{~m}), 1522(\mathrm{w}), 1510(\mathrm{~m})$, 1491 (m), 1463 (m), 1442 (m), 1415 (w) 1394 (w), 1351 (s), $1329(\mathrm{w}), 1291(\mathrm{w}), 1197(\mathrm{~m}), 1186(\mathrm{~s}), 1172(\mathrm{~s}), 1096(\mathrm{w})$, $1028(\mathrm{w}), 962(\mathrm{w}), 845(\mathrm{~m}), 835(\mathrm{~m}), 777(\mathrm{~s}), 700(\mathrm{w}), 645(\mathrm{~s})$ $\mathrm{cm}^{-1}$.

\section{Representative procedure for the synthesis of 3-tert-} butyl-5-(4-nitrophenyl)-1,2,4-oxadiazole (2)

To a mixture of $0.116 \mathrm{~g}(1 \mathrm{mmol})$ of tert-butylamidoxime in acetonitrile under an inert atmosphere was added $0.150 \mathrm{~g}$ $(1 \mathrm{mmol})$ of 4-nitrobenzonitrile in molar ratio 1:1. To this reaction mixture was added $0.3 \mathrm{mmol}(0.07 \mathrm{~g})$ of 2-mesitylenesulfonic acid and $0.3 \mathrm{mmol}(0.067 \mathrm{~g})$ of $\mathrm{ZnBr}_{2}$, and the mixture was heated to $80^{\circ} \mathrm{C}$ for 2 hours. After the reaction was finished the heating was removed, and the mixture was cooled to room temperature. The solvent was concentrated under reduced pressure, and ethyl acetate was added. The mixture was washed with sodium hydrogen carbonate solution, water and brine. The organic phase was dried over anhydrous sodium sulfate, filtered, and the solvent was removed. The resulting residue was dried in vacuum and flash chromatographed (silica, ethyl acetate/hexane $2: 1$ ), yielding after purification $0.232 \mathrm{~g}$ (0.94 mmol, $94 \%)$ of 2 as a white solid. MS m/z: $247\left(\mathrm{M}^{+}, 25\right)$, 232 (45), 150 (100); ${ }^{1} \mathrm{H}$ NMR (200 MHz, $\left.\mathrm{CDCl}_{3}\right) \delta 8.43-8.28$ (m, 4H), $1.45(\mathrm{~s}, 9 \mathrm{H}) ;{ }^{13} \mathrm{C}$ NMR $\left(50 \mathrm{MHz}, \mathrm{CDCl}_{3}\right) \delta 28.4,32.6$, 124.2, 129.9, 144.6, 148.9, 174.2, 178.4.

\section{Synthesis of 4-(4-(3-tert-butyl-1,2,4-oxadiazol-5-} yl)phenylamino)-4-oxobutanoic acid (3)

$0.3 \mathrm{~g}$ (1.38 mmol) of 4-(3-tert-butyl-1,2,4-oxadiazol-5yl)aniline (1) was mixed under inert conditions with an equimolar amount $(0.138 \mathrm{~g}, 1.38 \mathrm{mmol})$ of succinic anhydride in $20 \mathrm{~mL}$ of DCM. This mixture was vigorously stirred at room temperature for 5 hours. The remaining residue was freed from solvent, suspended in $50 \mathrm{~mL}$ of water, and the $\mathrm{pH}$ value adjusted to $2-3$ with a $1 \mathrm{~N}$ solution of $\mathrm{HCl}$. The resulting suspension was filtered, and the product was dried in vacuum. It was purified by flash chromatography (silica gel, ethyl acetate/ hexane 1:1), yielding $0.398 \mathrm{~g}(1.25 \mathrm{mmol}, 91 \%)$ of $\mathbf{3}$ as a white solid after purification. MS m/z: $317\left(\mathrm{M}^{+}, 15\right), 299$ (55), 217 (50), 202 (100), 120 (55); HRMS: calcd. for $\mathrm{C}_{16} \mathrm{H}_{19} \mathrm{~N}_{3} \mathrm{O}_{4}{ }^{+}$, 317.13701; found, 317.13717; ${ }^{1} \mathrm{H}$ NMR (200 MHz, DMSO- $d_{6}$ )

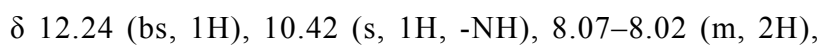
7.96-7.92 (m, 2H), 2.67-2.59 (m, 4H), $1.38(\mathrm{~s}, 9 \mathrm{H}) ;{ }^{13} \mathrm{C} \mathrm{NMR}$ $\left(50 \mathrm{MHz}, \mathrm{DMSO}-d_{6}\right) \delta 28.1\left(-\mathrm{CH}_{3}\right), 28.5,31.1,31.9,117.6$, $118.8,128.6,143.3,170.7,173.6,174.3,177.5$; mp 201-203 ${ }^{\circ} \mathrm{C}$; IR (ATR): 1/入 3385 (w), 2964 (w), 1696 (s), 1608 (m), $1594(\mathrm{w}), 1506$ (s), $1492(\mathrm{~m}), 1464(\mathrm{w}), 1410(\mathrm{~m}), 1394(\mathrm{w})$, $1351(\mathrm{~m}), 1337$ (m), 1313 (m), 1281 (w), 1249 (w), 1200 (m), $1177(\mathrm{~m}), 1159(\mathrm{~s}), 994(\mathrm{w}), 859(\mathrm{~m}), 830(\mathrm{w}), 802(\mathrm{w}), 773$ (m), $681(\mathrm{~m}), 612(\mathrm{~m}) \mathrm{cm}^{-1}$.

\section{Synthesis of 1-(4-(3-tert-butyl-1,2,4-oxadiazol-5- yl)phenyl)pyrrolidine-2,5-dione (4)}

$0.3 \mathrm{~g}(0.94 \mathrm{mmol})$ of 4-(4-(3-tert-butyl-1,2,4-oxadiazol-5yl)phenylamino)-4-oxobutanoic acid (3) was mixed with an equimolar amount of sodium acetate $(0.077 \mathrm{~g}, 0.94 \mathrm{mmol})$ in $15 \mathrm{~mL}$ of acetic anhydride, and the mixture was then heated for $4 \mathrm{~h}$ at $80-85^{\circ} \mathrm{C}$. After cooling, the product was washed with $100 \mathrm{~mL} \mathrm{H}_{2} \mathrm{O}$ at $\mathrm{pH} \approx 2-3$. The solid was dried in vacuum and flash chromatographed (silica, ethyl acetate/hexane 2:1), yielding after purification $0.244 \mathrm{~g}(0.81 \mathrm{mmol}, 87 \%)$ of 4 as a white solid. MS m/z: 299 ( $\left.\mathrm{M}^{+}, 55\right), 284$ (15), 202 (100); HRMS: calcd. for $\mathrm{C}_{16} \mathrm{H}_{17} \mathrm{~N}_{3} \mathrm{O}_{3}{ }^{+}, 299.12644$; found, 299.12695; ${ }^{1} \mathrm{H}$ NMR $\left(200 \mathrm{MHz}, \mathrm{CDCl}_{3}\right) \delta 8.18-8.09$ (m, 2H), 7.48-7.39 $(\mathrm{m}, 2 \mathrm{H}), 2.80(\mathrm{~s}, 4 \mathrm{H}), 1.34(\mathrm{~s}, 9 \mathrm{H}) ;{ }^{13} \mathrm{C} \mathrm{NMR}\left(50 \mathrm{MHz}, \mathrm{CDCl}_{3}\right)$ $\delta 28.3\left(-\mathrm{CH}_{3}\right), 32.3,124.2,126.6,128.6,135.3,174.0,175.5$, 178.3; mp 136-138 ${ }^{\circ} \mathrm{C}$; IR (ATR): 1/入 $2970(\mathrm{w}), 2875(\mathrm{w})$, 1776 (w), 1709 (s), 1613 (w), 1520 (w), 1500 (w), 1465 (w), 1419 (w), 1382 (m), 1351 (w), 1275 (w), 1197 (m), $1171(\mathrm{~s})$, $923(\mathrm{w}), 904(\mathrm{w}), 841(\mathrm{~m}), 810(\mathrm{w}), 771(\mathrm{w}), 737(\mathrm{w}), 697(\mathrm{~m})$, 659 (w) $\mathrm{cm}^{-1}$.

\section{Synthesis of methyl 4-(4-(3-tert-butyl-1,2,4-oxadi- azol-5-yl)phenylamino)-4-oxobutanoate (5)}

A suspension of $0.3 \mathrm{~g}(0.94 \mathrm{mmol})$ of 4-(4-(3-tert-butyl-1,2,4oxadiazol-5-yl)phenylamino)-4-oxobutanoic acid (3) in $10 \mathrm{~mL}$ of diethyl ether was cooled in an ice bath, and a solution of 
diazomethane in diethyl ether $2.5 \mathrm{~N}$ was added dropwise until the white solid disappeared, and the gas evolution stopped. The solvent was removed under high vacuum to afford $0.298 \mathrm{~g}$ ( $0.9 \mathrm{mmol}, 96 \%)$ of $\mathbf{5}$ as a white solid. No further purification was necessary. MS m/z: $331\left(\mathrm{M}^{+}, 10\right), 299$ (50), 284 (15), 202 (100); HRMS: calcd. for $\mathrm{C}_{17} \mathrm{H}_{21} \mathrm{~N}_{3} \mathrm{O}_{4}{ }^{+}$, 331.15266; found, $331.15275 ;{ }^{1} \mathrm{H}$ NMR $\left(200 \mathrm{MHz}, \mathrm{CDCl}_{3}\right) \delta 8.34$ (s, $\left.1 \mathrm{H}-\mathrm{NH}\right)$, 8.11-8.02 (m, 2H), 7.70-7.66 (m, 2H), $3.72(\mathrm{~s}, 3 \mathrm{H}), 2.82-2.67$ $(\mathrm{m}, 4 \mathrm{H}), 1.42(\mathrm{~s}, 9 \mathrm{H}) ;{ }^{13} \mathrm{C} \mathrm{NMR}\left(50 \mathrm{MHz}, \mathrm{CDCl}_{3}\right) \delta 27.8$ $\left(-\mathrm{CH}_{3}\right), 28.3,31.3,31.7,51.4,118.7,119.3,128.4,141.0$, $169.5,173.0,173.9,177.6 ; \mathrm{mp} 144-146{ }^{\circ} \mathrm{C}$; IR (ATR): $1 / \lambda$ $3391(\mathrm{w}), 2966(\mathrm{w}), 1738(\mathrm{~m}), 1702(\mathrm{~m}), 1607(\mathrm{~m}), 1595(\mathrm{w})$, 1507 (s), 1492 (m), $1524(\mathrm{w}), 1392$ (w), 1351 (m), 1327 (s), $1274(\mathrm{w}), 1251(\mathrm{w}), 1197(\mathrm{~m}), 1172(\mathrm{~s}), 1156(\mathrm{~s}), 1097(\mathrm{w}), 991$ (w), $988(\mathrm{w}), 863(\mathrm{~m}), 836(\mathrm{w}), 797(\mathrm{w}), 773(\mathrm{~m}), 699(\mathrm{w}), 690$ (w), $617(\mathrm{~s}) \mathrm{cm}^{-1}$.

Synthesis of (Z)-4-(4-(3-tert-butyl-1,2,4-oxadiazol-5yl)phenylamino)-4-oxobut-2-enoic acid (6)

$0.3 \mathrm{~g}(1.38 \mathrm{mmol})$ of 4-(3-tert-butyl-1,2,4-oxadiazol-5yl)aniline (1) was mixed under inert conditions with an equimolar amount of $0.135 \mathrm{~g}(1.38 \mathrm{mmol})$ of maleic anhydride in $20 \mathrm{~mL}$ of DCM. This mixture was vigorously stirred at room temperature for 3 hours. The remaining residue was freed from solvent and suspended in $50 \mathrm{~mL}$ of water, and the $\mathrm{pH}$ value was adjusted to 2-3 with a $1 \mathrm{~N}$ solution of $\mathrm{HCl}$. The resulting suspension was filtered, the product dried in vacuum and flash chromatographed (silica, ethyl acetate/hexane 2:1), yielding after purification $0.365 \mathrm{~g}(1.15 \mathrm{mmol}, 84 \%)$ of $\mathbf{6}$ as a white solid. MS m/z: $315\left(\mathrm{M}^{+}, 15\right), 297$ (50), 217 (55), 200 (100), 120 (75); HRMS: calcd. for $\mathrm{C}_{16} \mathrm{H}_{17} \mathrm{~N}_{3} \mathrm{O}_{4}{ }^{+}, 315.12136$; found, 315.12144; ${ }^{1} \mathrm{H}$ NMR (200 MHz, DMSO- $\left.d_{6}\right) \delta 12.94$ (bs, 1H), $10.73(\mathrm{~s}, 1 \mathrm{H},-\mathrm{NH}), 8.14-8.03(\mathrm{~m}, 2 \mathrm{H}), 7.96-7.85(\mathrm{~m}, 2 \mathrm{H})$, 6.61-6.32 (m, 2H), $1.38(\mathrm{~s}, 9 \mathrm{H}) ;{ }^{13} \mathrm{C}$ NMR (50 MHz, DMSO$\left.d_{6}\right) \delta 28.0\left(-\mathrm{CH}_{3}\right), 31.9,118.3,119.4,128.7,130.1,131.4$, $142.7,163.6,166.8,174.2,177.5$; mp 214-216 ${ }^{\circ} \mathrm{C}$; IR (ATR):

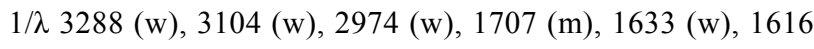
(w), $1586(\mathrm{~m}), 1566(\mathrm{w}), 1532$ (s), $1520(\mathrm{~s}), 1496(\mathrm{~s}), 1467$ (m), $1409(\mathrm{w}), 1396(\mathrm{w}), 1348(\mathrm{w}), 1325(\mathrm{~m}), 1281(\mathrm{w}), 1267(\mathrm{w})$, 1188 (m), 1101 (w), $976(\mathrm{~m}), 899$ (w), 849 (s), 776 (m), 737 (w), $738(\mathrm{w}), 632(\mathrm{w}), 615(\mathrm{~m}) \mathrm{cm}^{-1}$.

\section{Synthesis of 1-(4-(3-tert-butyl-1,2,4-oxadiazol-5- yl)phenyl)-1H-pyrrole-2,5-dione (7)}

$0.25 \mathrm{~g}$ (0.79 mmol) of (Z)-4-(4-(3-tert-butyl-1,2,4-oxadiazol-5yl)phenylamino)-4-oxobut-2-enoic acid (6) was mixed with an equimolar amount of sodium acetate $(0.065 \mathrm{~g}, 0.79 \mathrm{mmol})$ in $15 \mathrm{~mL}$ of acetic anhydride, and the mixture was then heated for $4 \mathrm{~h}$ at $80-85^{\circ} \mathrm{C}$. After cooling, the product was washed with $100 \mathrm{~mL}$ of water at $\mathrm{pH} \approx 2-3$. The solid was dried in vacuum and flash chromatographed (silica, ethyl acetate/hexane 2:1), yielding after purification $0.176 \mathrm{~g}(0.59 \mathrm{mmol}, 75 \%)$ of 7 as a white solid. MS m/z: 297 (M $\left.\mathrm{M}^{+}, 60\right), 282$ (15), 200 (100); HRMS: calcd. for $\mathrm{C}_{16} \mathrm{H}_{15} \mathrm{~N}_{3} \mathrm{O}_{3}{ }^{+}$, 297.11079; found, 297.11127; ${ }^{1} \mathrm{H}$ NMR $\left(200 \mathrm{MHz}, \mathrm{CDCl}_{3}\right) \delta 8.26-8.14(\mathrm{~m}, 2 \mathrm{H}), 7.62-7.54$ $(\mathrm{m}, 2 \mathrm{H}), 6.88(\mathrm{~s}, 2 \mathrm{H}), 1.44(\mathrm{~s}, 9 \mathrm{H}) ;{ }^{13} \mathrm{C} \mathrm{NMR}\left(50 \mathrm{MHz}, \mathrm{CDCl}_{3}\right)$ $\delta 28.2\left(-\mathrm{CH}_{3}\right), 32.3,123.2,125.5,128.5,134.2,134.8,168.6$, 174.0, 178.3; mp 123-125 ${ }^{\circ} \mathrm{C}$; IR (ATR): $1 / \lambda 3474$ (w), 3096 (w), 2975 (w), 2927 (w), 1713 (s), 1614 (w), 1567 (w), 1521 (m), 1502 (m), 1466 (w), 1395 (m), 1385 (m), $1351(\mathrm{w}), 1306$ (w), $1238(\mathrm{w}), 1195(\mathrm{~m}), 1149(\mathrm{~s}), 1064(\mathrm{w}), 1022(\mathrm{w}), 988(\mathrm{w})$, $949(\mathrm{w}), 905(\mathrm{w}), 842(\mathrm{~m}), 827(\mathrm{~s}), 771(\mathrm{~m}), 737(\mathrm{w}), 700(\mathrm{~s})$, $686(\mathrm{~m}), 652(\mathrm{w}), 624(\mathrm{w}) \mathrm{cm}^{-1}$.

\section{X-ray structure determinations}

Data are summarized in Table 2. Intensities were determined at $100 \mathrm{~K}$ on Oxford Diffraction diffractometers by using monochromated Mo K $\alpha$ or mirror-focussed $\mathrm{Cu} \mathrm{K} \alpha$ radiation. Structures were refined on $F^{2}$ using the program SHELXL-97 [38]. Hydrogen atoms were refined either freely $(\mathrm{NH})$, by using rigid methyl groups allowed to rotate but not tip or by using a riding model starting from calculated positions. Structure 5 was treated as a non-merohedral twin.

CCDC-924911 (1), CCDC-951265 (2), CCDC-924912 (4), CCDC-924913 (5), CCDC-924914 (6) contain the supplementary crystallographic data for this paper. These data can be obtained free of charge from the Cambridge Crystallographic Data Centre via http://www.ccdc.cam.ac.uk/.

\section{In vitro antitumor activity toward human tumor cell lines}

Antitumor activity of the compounds was tested in a monolayer cell survival and proliferation assay with human tumor cell lines. Studies carried out with panels of human tumor cell lines of different origin and histotype allow for the analysis of potency and tumor selectivity of test compounds.

Ten out of the eleven tested cell lines were established at Oncotest from patient-derived human tumor xenografts passaged subcutaneously in nude mice [39]. The origin of the donor xenografts was described [40,41]. The cell line HT-29 was kindly provided by the National Cancer Institute (Bethesda, MA, USA). Cells were cultured in RPMI 1640 medium, supplemented with $10 \%$ fetal calf serum and $0.1 \mathrm{mg} / \mathrm{mL}$ gentamicin under standard conditions $\left(37^{\circ} \mathrm{C}, 5 \% \mathrm{CO}_{2}\right)$. Authenticity of all cell lines was proven by STR analysis at the DSMZ (Braunschweig, Germany).

A modified propidium iodide assay was used to assess the compounds' activity toward human tumor cell lines [42]. Briefly, cells were harvested from exponential phase cultures by 


\begin{tabular}{|c|c|c|c|c|c|}
\hline Compound & 1 & 2 & 4 & 5 & 6 \\
\hline Formula & $\mathrm{C}_{12} \mathrm{H}_{15} \mathrm{~N}_{3} \mathrm{O}$ & $\mathrm{C}_{12} \mathrm{H}_{137} \mathrm{~N}_{3} \mathrm{O}_{3}$ & $\mathrm{C}_{16} \mathrm{H}_{17} \mathrm{~N}_{3} \mathrm{O}_{3}$ & $\mathrm{C}_{17} \mathrm{H}_{21} \mathrm{~N}_{3} \mathrm{O}_{4}$ & $\mathrm{C}_{17} \mathrm{H}_{21} \mathrm{~N}_{3} \mathrm{O}_{4}$ \\
\hline$M_{\mathrm{r}}$ & 217.27 & 247.25299 .33 & 299.33 & 331.37 & 331.37 \\
\hline Habit & colourless tablet & colourless tablet & colourless needle & colourless plate & colourless prism \\
\hline Cryst. size (mm) & $0.15 \times 0.15 \times 0.1$ & $0.24 \times 0.12 \times 0.07$ & $0.11 \times 0.05 \times 0.02$ & $0.18 \times 0.09 \times 0.02$ & $0.07 \times 0.05 \times 0.03$ \\
\hline Crystal system & monoclinic & orthorhombic & monoclinic & monoclinic & trigonal \\
\hline Space group & $\mathrm{P} 2{ }_{1} / \mathrm{C}$ & Pbca & $\mathrm{P} 2{ }_{1} / \mathrm{C}$ & $P \overline{1}$ & $R \overline{3}$ \\
\hline \multicolumn{6}{|l|}{ Cell constants: } \\
\hline$a(\AA)$ & $15.6514(10)$ & $6.7175(4)$ & $13.8569(4)$ & $5.4494(5)$ & $28.0192(6)$ \\
\hline$b(\AA)$ & $9.0961(6)$ & $13.8116(6)$ & $15.3562(4)$ & $6.1403(6)$ & $28.0192(6)$ \\
\hline$c(\AA)$ & $18.4999(12)$ & $26.1018(9)$ & $6.8926(2)$ & $25.283(2)$ & $10.0740(8)$ \\
\hline$\alpha\left({ }^{\circ}\right)$ & 90 & 90 & 90 & $86.906(8)$ & 90 \\
\hline$\beta\left(\left(^{\circ}\right)\right.$ & $114.371(8)$ & 90 & $94.918(2)$ & $85.277(8)$ & 90 \\
\hline$Y\left({ }^{\circ}\right)$ & 90 & 90 & 90 & $72.926(8)$ & 120 \\
\hline$V\left(\AA^{3}\right)$ & 2399.1 & 2421.7 & 1461.27 & 805.57 & 6849.3 \\
\hline Z & 8 & 8 & 4 & 2 & 18 \\
\hline$D_{\mathrm{x}}\left(\mathrm{Mg} \mathrm{m}^{-3}\right)$ & 1.203 & 1.356 & 1.361 & 1.366 & 1.376 \\
\hline$\mu\left(\mathrm{mm}^{-1}\right)$ & 0.08 & 0.10 & 0.80 & 0.81 & 0.84 \\
\hline$F(000)$ & 928 & 1040 & 632 & 352 & 2988 \\
\hline$T\left({ }^{\circ} \mathrm{C}\right)$ & -173 & -173 & -173 & -173 & -173 \\
\hline Wavelength $(\AA)$ ) & 0.71073 & 0.71073 & 1.54184 & 1.54184 & 1.54184 \\
\hline $2 \theta_{\max }$ & 52.8 & 56.6 & 152 & 152 & 152 \\
\hline Refl. measured & 41755 & 55696 & 16680 & & 28530 \\
\hline Refl. indep. & 4908 & 2483 & 3034 & 3747 & 3156 \\
\hline$R_{\text {int }}$ & 0.064 & 0.074 & 0.027 & & 0.067 \\
\hline Parameters & 311 & 166 & 202 & 226 & 219 \\
\hline$w R\left(F^{2}\right.$, all refl. $)$ & 0.057 & 0.061 & 0.086 & 0.179 & 0.098 \\
\hline$R(F,>4 \sigma(F))$ & 0.035 & 0.031 & 0.032 & 0.062 & 0.039 \\
\hline S & 0.73 & 0.81 & 1.06 & 1.07 & 1.04 \\
\hline $\max . \Delta / \rho\left(\mathrm{e} \AA^{-3}\right)$ & 0.17 & 0.18 & 0.21 & 0.38 & 0.17 \\
\hline
\end{tabular}

trypsinization, counted and plated in 96-well flat-bottom microtiter plates at a cell density dependent on the cell line (4.000-20.000 cells/well). After $24 \mathrm{~h}$ recovery period to allow the cells to adhere and resume exponential growth, compounds were added at 10 concentrations in half-log increments and incubated for 4 days. The inhibition of proliferation was determined by measuring the DNA content with an aqueous propidium iodide solution $(7 \mu \mathrm{g} / \mathrm{mL})$. Fluorescence was measured by using a Cytofluor micro-plate reader (excitation $\lambda=530 \mathrm{~nm}$, emission $\lambda=620 \mathrm{~nm}$ ) and thus establishing a direct relationship to the total viable cell number. In each experiment, all measurements were carried out twice.

\section{Acknowledgements}

We like to thank Dr. Constantin Daniliuc for the measurement and analysis of the X-ray data. This work was supported by the Romanian National Authority for Scientific Research (EXPLORATORY RESEARCH PROGRAM IDEI-PCE-
PROJECT NR. 341-/05.10.2011 - Immunomodulatory Fluoroglycopeptide Molecular Architectures, Ion Neda).

\section{References}

1. Jochims, J. C. 1,2,4-Oxadiazoles. In Five-membered rings with more than two heteroatoms and fused carbocyclic derivatives; Katritzky, A. R.; Rees, C. W.; Scriven, E. V. F., Eds.; Comprehen-sive Heterocyclic Chemistry II, Vol. 4; Pergamon Press: London, 1996; pp 179-228.

2. Vu, C. B.; Corpuz, E. G.; Merry, T. J.; Pradeepan, S. G.; Bartlett, C.; Bohacek, R. S.; Botfield, M. C.; Eyermann, C. J.; Lynch, B. A.; MacNeil, I. A.; Ram, M. K.; van Schravendijk, M. R.; Violette, S.; Sawyer, T. K. J. Med. Chem. 1999, 42, 4088-4098. doi:10.1021/jm990229t

3. Carbone, M.; Li, Y.; Irace, C.; Mollo, E.; Castelluccio, F.; Di Pascale, A.; Cimino, G.; Santamaria, R.; Guo, Y.-W.; Gavagnin, M. Org. Lett. 2011, 13, 2516-2519. doi:10.1021/ol200234r

4. Brogan, J. T.; Stoops, S. L.; Lindsley, C. W. ACS Chem. Neurosci. 2012, 3, 658-664. doi:10.1021/cn300064r 
5. Takemoto, T.; Takagi, N.; Nakajima, T.; Koike, K. Yakugaku Zasshi 1975, 95, 176-179.

6. Flippen, J. L.; Gilardi, R. D. Acta Crystallogr., Sect. B 1976, 32, 951-953. doi:10.1107/S0567740876004299

7. Jin, R.; Horning, M.; Mayer, M. L.; Gouaux, E. Biochemistry 2002, 41, 15635-15643. doi:10.1021/bi020583k

8. Zhang, H.-Z.; Kasibhatla, S.; Kuemmerle, J.; Kemnitzer, W.; Ollis-Mason, K.; Qiu, L.; Crogan-Grundy, C.; Tseng, B.; Drewe, J.; Cai, S. X. J. Med. Chem. 2005, 48, 5215-5223. doi:10.1021/jm050292k

9. Fujii, S.; Ohta, K.; Goto, T.; Kagechika, H.; Endo, Y. Bioorg. Med. Chem. 2009, 17, 344-350. doi:10.1016/j.bmc.2008.10.060

10. Boys, M. L.; Schretzman, L. A.; Chandrakumar, N. S.; Tollefson, M. B.; Mohler, S. B.; Downs, V. L.; Penning, T. D.; Russell, M. A.; Wendt, J. A.; Chen, B. B.; Stenmark, H. G.; Wu, H.; Spangler, D. P.; Clare, M.; Desai, B. N.; Khanna, I. K.; Nguyen, M. N.; Duffin, T.; Engleman, V. Q.; Finn, M. B.; Freeman, S. K.; Hanneke, M. L.; Keene, J. L.; Klover, J. A.; Nickols, G. A.; Nickols, M. A.; Steininger, C. N.; Westlin, M.; Westlin, W.; Yu, Y. X.; Wang, Y.; Dalton, C. R.; Norring, S. A. Bioorg. Med. Chem. Lett. 2006, 16, 839-844. doi:10.1016/j.bmcl.2005.11.008

11. Diana, G. D.; Volkots, D. L.; Nitz, T. J.; Bailey, T. R.; Long, M. A.; Vescio, N.; Aldous, S.; Pevear, D. C.; Dutko, F. J. J. Med. Chem. 1994, 37, 2421-2436. doi:10.1021/jm00041a022

12. Watjen, F.; Baker, R.; Engelstoff, M.; Herbert, R.; MacLeod, A.; Knight, A.; Merchant, K.; Moseley, J.; Saunders, J.; Swain, C. J.; Wong, E.; Springer, J. P. J. Med. Chem. 1989, 32, 2282-2291. doi:10.1021/jm00130a010

13. Bezerra, N. M. M.; De Oliveira, S. P.; Srivastava, R. M.; Da Silva, J. R. Farmaco 2005, 60, 955-960. doi:10.1016/j.farmac.2005.08.003

14. Orlek, B. S.; Blaney, F. E.; Brown, F.; Clark, M. S. G.; Hadley, M. S.; Hatcher, J.; Riley, G. J.; Rosenberg, H. E.; Wadsworth, H. J.; Wyman, P. J. J. Med. Chem. 1991, 34, 2726-2735. doi:10.1021/jm00113a009

15. Swain, C. J.; Baker, R.; Kneen, C.; Moseley, J.; Saunders, J.; Seward, E. M.; Stevenson, G.; Beer, M.; Stanton, J.; Watling, K. J. Med. Chem. 1991, 34, 140-151. doi:10.1021/jm00105a021

16. Ankersen, M.; Peschke, B.; Hansen, B. S.; Hansen, T. K. Bioorg. Med. Chem. Lett. 1997, 7, 1293-1298. doi:10.1016/S0960-894X(97)00216-3

17. Kratz, F.; Müller-Driver, R.; Hofmann, I.; Drevs, J.; Unger, C. J. Med. Chem. 2000, 43, 1253-1256. doi:10.1021/jm9905864

18. Kratz, F.; Warnecke, A.; Scheuermann, K.; Stockmar, C.; Schwab, J.; Lazar, P.; Drückes, P.; Esser, N.; Drevs, J.; Rognan, D.; Bissantz, C.; Hinderling, C.; Folkers, G.; Fichtner, I.; Unger, C. J. Med. Chem. 2002, 45, 5523-5533. doi:10.1021/jm020276c

19. Warnecke, A.; Kratz, F. Bioconjugate Chem. 2003, 14, 377-387. doi:10.1021/bc0256289

20. Kratz, F.; Beyer, U. Drug Delivery 1998, 5, 281-299. doi:10.3109/10717549809065759

21. Maeda, H.; Wu, J.; Sawa, T.; Matsumura, Y.; Hori, K. J. Controlled Release 2000, 65, 271-284. doi:10.1016/S0168-3659(99)00248-5

22. Lopez, S.; Castelli, M.; de Campos, F.; Correa, R.; Cechinel Filho, V.; Yunes, R.; Zamora, M.; Enriz, R.; Ribas, J.; Furlan, R.; Zacchino, S. Arzneim. Forsch. 2005, 55, 123-132.

23. Derita, M.; Castelli, M.; Sortino, M. In Manual de Técnicas in vitro para la Detección de Compuestos Antifúngicos; Zacchino, S.; Gupta, M., Eds.; Corpus: Rosario: Argentina, 2007; pp 75-84.
24. Cos, P.; Vlietinck, A.; Vanden Berghe, D.; Maes, L. J. Ethnopharmacol. 2006, 106, 290-320. doi:10.1016/j.jep.2006.04.003

25. CLSI, Clinical and Laboratory Standards Institute Document M27-A3, 3rd ed.; Wayne Ed.; NCCLS: Pennsylvania, 2008; Vol. 28, pp 1-25.

26. CLSI, Clinical and Laboratory Standards Institute Document M38-A2, 2nd ed.; Wayne Ed.; NCCLS: Pennsylvania, 2008; Vol. 28, pp 1-35.

27. Sortino, M.; Cechinel Filho, V.; Corrêa, R.; Zacchino, S. Bioorg. Med. Chem. 2008, 16, 560-568. doi:10.1016/j.bmc.2007.08.030

28. Barret, D. Biochim. Biophys. Acta 2002, 1587, 224-233. doi:10.1016/S0925-4439(02)00085-6

29. Fujinami, A.; Ozaki, T.; Yamamoto, S. Agric. Biol. Chem. 1971, 35 , 1707-1719. doi:10.1271/bbb1961.35.1707

30. Fujinami, A.; Ozaki, T.; Nodera, K.; Tanaka, K. Agric. Biol. Chem. 1972, 36, 318-323. doi:10.1271/bbb1961.36.318

31. Rankin, G. O. Toxicology 1982, 23, 21-31. doi:10.1016/0300-483X(82)90038-5

32. Sugihara, S.; Shinohara, Y.; Miyata, Y.; Inoue, K.; Ito, N. Lab. Invest. 1975, 33, 219-230.

33. Clapp, L. B. Adv. Heterocycl. Chem. 1976, 20, 65-116. doi:10.1016/S0065-2725(08)60852-1

34. Maftei, C. V.; Fodor, E.; Mangalgaiu, I.; Jones, P. G.; Daniliuc, C. G.; Franz, M. H.; Neda, I. Rev. Roum. Chim. 2010, 55, 989-994.

35. Maurer, F.; Fuchs, R.; Erdelen, C.; Turberg, A. Substituierte Pyrazoline als Schädlingsbekämpfungsmittel. WO2003059887 A1, July 24, 2003.

36. Maurer, F.; Erdelen, C.; Reckmann, U. Oxadiazolyl- und Thiadiazolyl-benzoylharnstoffe. Ger. Patent Appl. DE10139721 A1, Feb 27, 2003.

37. Augustine, J. K.; Akabote, V.; Hegde, S. G.; Alagarsamy, P. J. Org. Chem. 2009, 74, 5640-5643. doi:10.1021/jo900818h

38. Sheldrick, G. M. Acta Crystallogr., Sect. A 2008, 65, 112-122. doi:10.1107/S0108767307043930

39. Roth, T.; Burger, A. M.; Dengler, W.; Willmann, H.; Fiebig, H. H. Human tumor cell lines demonstrating the characteristics of the patient tumors as useful models for anticancer drug screening. In Relevance of Tumor Models for Anticancer Drug Development; Fiebig, H. H.; Burger, A. M., Eds.; Contribution to Oncology, Vol. 54; Karger: Basel, Switzerland, 1999; pp 145-156.

40. Fiebig, H. H.; Dengler, W. A.; Roth, T. Human Tumor Xenografts: Predictivity, Characterization, and Discovery of New Anticancer Agents. In Relevance of Tumor Models for Anticancer Drug Development; Fiebig, H. H.; Burger, A. M., Eds.; Contribution to Oncology, Vol. 54; Karger: Basel, Switzerland, 1999; pp 29-50.

41. Fiebig, H. H.; Berger, D. P.; Dengler, W. A.; Wallbrecher, E.; Winterhalter, B. R. Strahlenther. Onkol. 1992, 42, 321-351.

42. Dengler, W. A.; Schulte, J.; Berger, D. P.; Mertelsmann, R.; Fiebig, H. H. Anti-Cancer Drugs 1995, 6, 522-532. doi:10.1097/00001813-199508000-00005 


\section{License and Terms}

This is an Open Access article under the terms of the Creative Commons Attribution License

(http://creativecommons.org/licenses/by/2.0), which permits unrestricted use, distribution, and reproduction in any medium, provided the original work is properly cited.

The license is subject to the Beilstein Journal of Organic Chemistry terms and conditions:

(http://www.beilstein-journals.org/bjoc)

The definitive version of this article is the electronic one which can be found at:

doi:10.3762/bjoc.9.259 